carrying forward the improvements in reduced caries experience in children into adulthood, are specific to agecohorts. Other issues are more universal: how to respond to the phenomenon of more teeth and of more (and different) diseases and disorders. That response must also include a better understanding of dental self-care and professional dental care and how they contribute to oral wellbeing.

\section{REFERENCES}

1. Bailit HL. Changing patterns of oral health and implications for oral health manpower: Responsibility to the public. Int Dent J 1988; 38: 56-60.

2. Christianson ML. Lifetime dental health monitoring: An agerelated preventive strategy. In: Epidemiologic and clinical evidence and policy implications. San Francisco: Health Policy Program, University of California, 1977.

3. Lewis DW (Chairman). Preventive dental services: Practices, guidelines and recommendations. Report of the Working Group on Preventive Dental Services. Ottawa: Health and Welfare Canada, 1979.

4. Spencer AJ, Davies M, Slade G, Brennan D. Caries prevalence in Australasia. Int Dent J 1994; 44: 415-23.

5. NHMRC. The effectiveness of water fluoridation. Canberra: NHMRC, 1991.

6. Spencer AJ, Slade GD, Davies M. Water fluoridation in Australia. Community Dent Health 1996; 13 (Suppl. 2) : 2737.

7. Hausen H. Caries prediction: State of the art. Community Dent Oral Epidemiol 1997; 25: 87-96.

8. Stamm JW, Stewart PW, Bohannan HM, Disney JA, Graves RC, Abernathy JR. Risk assessment for oral diseases. $A d v$ Dent Res 1991; 5: 4-17.
9. Spencer AJ, Allister JH, Brennan DS. Predictors of fixed orthodontic treatment in 15 year old adolescents in South Australia. Community Dent Oral Epidemiol 1995; 23: 350-5.

10. Downer MC. Craniofacial anomalies: Are they a public health problem? Int Dent J 1987; 37: 193-6.

11. Stockwell AJ. Incidence of dental trauma in the Western Australian school dental service. Community Dent Oral Epidemiol 1988; 16: 294-8.

12. Rodd HD, Chesham DJ. Sports-related oral injury and mouthguard use among Sheffield School children. Community Dent Health 1997; 14: 25-30.

13. Brennan DS, Carter KD, Stewart JF, Spencer AJ. Commonwealth Dental Health Program Evaluation Report 1994-1996. Adelaide: AIHW Dental Statistics and Research Unit, The University of Adelaide, 1997.

14. Burt BA. How useful are cross-sectional data from surveys of dental caries? Community Dent Oral Epidemiol 1997; 25: $36-41$.

15. Spencer AJ. Caries activity of age cohorts in the Australian population. Aust Dent Assoc News Bulletin 1997; 245: 8, $11-4$.

16. Gruenberg EM. The failures of success. Milbank Mem Fund Quarterly 1977; 55: 3-34.

17. Verbrugge LM. Longer life but worsening health? Trends in health and mortality of middle-aged and older persons. Milbank Mem Fund Quarterly 1984; 62: 475-519.

18. Joshi A, Douglass CW, Feldman H, Mitchell P, Jette A. Consequences of success: Do more teeth translate into more disease and utilization? J Pub Health Dent 1996; 56: 190-7.

19. Davidson PL, Cunningham WE, Nakazono TT, Andersen RM. Evaluating the effect of usual source of dental care on access to dental services: Comparisons among diverse populations. Med Care Res and Review 1999; 56: 74-93.

20. Slade GD, ed. Measuring oral health and quality of life. Chapel Hill: University of North Carolina, Dental Ecology, 1997. it

\title{
THE SOKS PROGRAM
}

The Save Our Kids Smiles (SOKS) program, implemented in 1996, is an oral health assessment and promotion program for school-aged children. Oral assessments are offered at school for children in kindergarten and years two, four, six and eight attending Catholic, Government and Independent schools. Oral health promotion is also provided in the classroom.

Data from the 1997 SOKS assessments show that, after adjusting for age, the proportion of children with dental caries (measured by the average number of teeth that are decayed, missing or filled due to caries) was significantly higher in rural Area Health Services and lower in metropolitan Area Health Services when compared with
NSW as a whole. ${ }^{1}$ Similarly, the proportion of children with untreated decay was higher in rural and lower in metropolitan Area Health Services. ${ }^{1}$

Data from the first three years of the SOKS assessments are currently being analysed and a report will be available later this year. The SOKS program itself is currently being evaluated and results will be available in early 2000 .

\section{REFERENCES}

1. Epidemiology and Surveillance Branch. 1999/2000-2000/ 2001 NSW Performance Agreements: AHS Health Status Profiles. NSW Health Department. www.healthnsw.gov.au/ public-health/pubs.html. 